\title{
Depth interactions and reproductive ecology of sympatric Sillaginidae: Sillago robusta and S. flindersi
}

\author{
Charles A. Gray ${ }^{1,2,3, *}$, Lachlan M. Barnes ${ }^{1,4}$, Dylan E. van der Meulen ${ }^{1,5}$, \\ Benjamin W. Kendall ${ }^{1,6}$, Faith A. Ochwada-Doyle ${ }^{1,7}$, William D. Robbins ${ }^{1,8}$ \\ ${ }^{1}$ NSW Primary Industries, Cronulla Fisheries Research Centre, Cronulla, NSW 2230, Australia \\ Present addresses: ${ }^{2}$ WildFish Research, Grays Point, Sydney, NSW 2232, Australia \\ ${ }^{3}$ University of New South Wales, Randwick, NSW 2052, Australia \\ ${ }^{4}$ Cardno, St Leonards, NSW 2065, Australia \\ ${ }^{5}$ Batemans Bay Fisheries Centre, NSW 2536, Australia \\ ${ }^{6}$ Seglaregatan, Gothenburg 41457, Sweden \\ ${ }^{7}$ Sydney Institute of Marine Science, Mosman, NSW 2088, Australia \\ ${ }^{8}$ Wildlife Marine, Sorrento, Perth, WA 6020, Australia
}

\begin{abstract}
This study examined whether differences existed in the depth distributions and reproductive strategies of the co-occurring Sillago robusta and $S$. flindersi in coastal waters off eastern Australia. Marked spatial and temporal dissimilarities in demography and reproduction were observed between the 2 species, with $S$. robusta being more abundant in the shallow $(15-30 \mathrm{~m})$ strata and $S$. flindersi in the mid $(31-60 \mathrm{~m})$ strata, with neither species being consistently abundant in the deep (61-90 m) strata. The size composition of $S$. robusta was similar across depths, but smaller and immature $S$. flindersi predominantly occurred in the shallow strata, with larger and mature individuals occurring deeper. These data indicate partitioning of habitat resources, which may aid species coexistence. Both species potentially spawned year-round, which is probably an adaptation to the region's dynamic coastal environment. However, a greater proportion of $S$. robusta was in spawning condition between September and March, whereas $S$. flindersi displayed no such temporal pattern. Maturity ogives differed significantly between sexes and locations for both species. Both species displayed similar ovarian development, with females having multiple concurrent oocyte stages, indicating potential multiple spawning events as evidenced in other Sillaginidae. For both species, estimated batch fecundity increased with fish length, but $S$. robusta had a greater fecundity at any given length than $S$. flindersi. In contrast, $S$. flindersi potentially produced larger-sized eggs and invested greater energy into gonad development than $S$. robusta, indicating the 2 species have evolved slightly different reproductive strategies. Despite this, both species are subjected to substantial trawl fisheries, which may have already impacted their reproductive ecologies.
\end{abstract}

KEY WORDS: Life history $\cdot$ Habitat partitioning $\cdot$ Population structure $\cdot$ Reproduction $\cdot$ Maturity $\cdot$ Spawning $\cdot$ Fishery exploitation

\section{INTRODUCTION}

Knowledge of the life history characteristics of cooccurring species is fundamental to understanding biotic processes that influence structure and maintenance of assemblages of organisms (Schoener 1974,

${ }^{*}$ Corresponding author: charles.gray@wildfishresearch.com.au
Ross 1986, Roff 1992). Closely related teleost species that coexist often display different life history characteristics, such as reproductive and recruitment strategies, diets and small-scale distributions and abundances (Ross 1977, Roff 1991, Hyndes et al. 1997, Genner et al. 1999, Colloca et al. 2010). Such strate-

() The authors 2014. Open Access under Creative Commons by Attribution Licence. Use, distribution and reproduction are unrestricted. Authors and original publication must be credited. 
gies maximise partitioning of resources, minimise the potential for interspecific competition, and may contribute to the coexistence of different assemblages and thus affect assemblage structure (Schoener 1974, Werner et al. 1977, Ross 1986).

Members of the teleost family Sillaginidae (whiting) inhabit subtropical and temperate coastal shelf and estuarine waters of the Indian and Western Pacific Oceans (McKay 1992, www.fishbase.org). The family contains 31 species, of which 13 occur in Australian waters, with 6 of these distributed along the east coast (McKay 1992). Sillaginids display a high degree of similarity in coloration and external morphology, having slender elongate fusiform-shaped bodies and long conical snouts. Most species attain maximum total lengths less than $40 \mathrm{~cm}$ and longevities under 12 yr (McKay 1992, Kendall \& Gray 2009). Sillaginids are benthic carnivores that feed on small invertebrates such as polychaetes and crustaceans (Gunn \& Milward 1985, Hyndes et al. 1997, Hajisamae et al. 2006) and can be a prominent component of soft-sediment benthic ichthyofaunas (Gray \& Otway 1994, Chen et al. 2009, Gray et al. 2011, Nakane et al. 2013). Several species are important in commercial, recreational and artisanal fisheries (McKay 1992, Kailola et al. 1993, Gray \& Kennelly 2003).

Life history and ecological aspects of several sillaginid species have been investigated; notably the coastal shelf species Sillago sihama in Indian waters (Radhakrishnan 1957, Reddy \& Neelakantan 1992, Hajisamae et al. 2006, Shamsan \& Ansari 2010), S. aeolus in Japanese waters (Rahman \& Tachihara 2005a, b), Sillaginodes punctata off southern and south-western Australia (Fowler \& Short 1996, Hyndes et al. 1998, Fowler et al. 1999, 2000), and Sillago analis, $S$. burrus, $S$. vittata, S. robusta, S. schomburgkii and $S$. bassensis off western Australia (Coulson et al. 2005, Hyndes \& Potter 1996, 1997, Hyndes et al. 1996a,b, 1997). Similarly, the demographic characteristics of the estuarine-nearshore distributed $S$. ciliata, $S$. maculata and $S$. analis have been examined in eastern Australia (Cleland 1947, Burchmore et al. 1988, Kendall \& Gray 2009, Stocks et al. 2011). There have been few investigations of the biological characteristics of the eastern Australian coastal shelf species $S$. robusta and $S$. flindersi, even though they are the most abundant sillaginids inhabiting these waters and are subject to substantial (approximately $2000 \mathrm{t}$ per annum) commercial fisheries (Rowling et al. 2010).

The distributions of $S$. robusta and $S$. flindersi overlap off eastern Australia; S. robusta consists of 2 disparate populations extending between approximately $24^{\circ} \mathrm{S}$ and $34^{\circ} \mathrm{S}$ on the west and east coasts, whereas $S$. flindersi is endemic to the east and southern mainland coasts as well as around northeastern Tasmania, occurring between approximately $25^{\circ} \mathrm{S}$ and $44^{\circ} \mathrm{S}$ (Fig. 1). Both species are an important byproduct in coastal penaeid trawl fisheries (Kennelly et al. 1998, Macbeth et al. 2012), whilst S. robusta is targeted in a limited entry quota-based trawl fishery in its northern distribution (Butcher \& Hagedoorn 2003, Zeller et al. 2012). In contrast, S. flindersi is taken across several multi-sector trawl and Danishseine fisheries managed by different jurisdictions throughout its distribution (Kemp et al. 2012). Depending on the jurisdiction, different input and output controls are used as management tools for each species, including limited entry, fishing gear and vessel restrictions, spatial and temporal closures, legal length limits and total allowable catches. Concerns over discarding in some fisheries have resulted in the development of fishing gears that are more selective at retaining market-sized sillaginids (Broadhurst et al. 2005, Graham et al. 2009). Similar attention to resolving the biological parameters of these species has not taken place. Little is known about important aspects of the reproductive biology of either species, including lengths and ages at maturity, and modes, times and locations of spawning. Without such information, appropriate fishery and species management plans cannot be evaluated.

Previous studies show that sillaginids generally attain sexual maturity at young ages (1 to $3 \mathrm{yr}$ ), spawn multiple times over protracted spawning seasons,

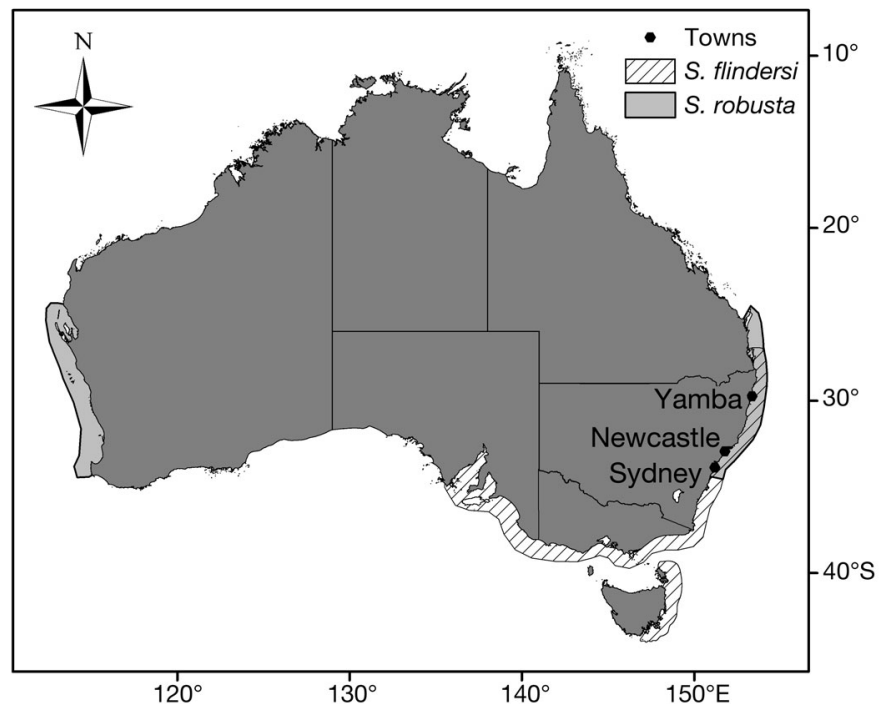

Fig. 1. Distribution of Sillago robusta and S. flindersi throughout Australia and the Yamba and Newcastle sampling locations off eastern Australia 
and display depth-associated ontogenetic shifts in distribution that may assist partitioning of resources (Burchmore et al. 1988, Hyndes et al. 1996a,b, 1997 , Kendall \& Gray 2009). Here we investigate whether this general paradigm is applicable to $S$. robusta and $S$. flindersi where their distributions overlap in coastal waters off eastern Australia. We specifically test whether the relative abundances, length compositions and reproductive characteristics of populations of these species differ temporally, and between depths and locations.

\section{MATERIALS AND METHODS}

\section{Study area and sampling procedures}

Sampling was conducted in inner-continental shelf waters (<100 $\mathrm{m}$ depth) across transects adjacent to Yamba $\left(29^{\circ} 26^{\prime} \mathrm{S}, 153^{\circ} 20^{\prime} \mathrm{E}\right)$ and Newcastle $\left(32^{\circ} 55^{\prime} \mathrm{S}\right.$, $151^{\circ} 45^{\prime} \mathrm{E}$ ) off eastern Australia (Fig. 1). This region is characterised by a dynamic oceanography dominated by the southward flowing East Australian Current and associated eddies (Huyer et al. 1988, Roughan \& Middleton 2004, Suthers et al. 2011). The water column is usually thermally stratified in summer but not always in winter, with surface water temperatures typically oscillating between a mean maximum of 24 to $26^{\circ} \mathrm{C}$ in late summer (February-March) to a mean maximum of 13 to $15^{\circ} \mathrm{C}$ in late winter/spring (August-September).

Sampling at both locations was stratified across 3 depth ranges; 15-30 m, 31-60 $\mathrm{m}$ and 61-90 m; hereafter referred to as the shallow, mid and deep strata respectively. The middle of each depth range corresponded to a distance of approximately 3,13 and $26 \mathrm{~km}$ offshore at Yamba and 1,7 and $10 \mathrm{~km}$ at Newcastle. All sampling was done over soft substrata where commercial trawling for penaeid prawns and whiting regularly occurs. Sampling took place at night within 1 week of the full moon, every 4 weeks at both locations. Sampling extended for 2 full years between November 2005 and November 2007 at Yamba and between October 2006 and November 2007 at Newcastle. Samples were collected using a chartered ocean prawn trawl vessel from each port rigged with standard regulated 'triple' gear, in which each of the 3 nets had a headline length of $10.8 \mathrm{~m}$, stretched mesh of $42 \mathrm{~mm}$ hung on the diamond throughout the body and cod-end, the latter which had a circumference of 100 meshes. The general selectivity of $S$. flindersi in this penaeid fishing gear configuration is reported in Broadhurst et al. (2005).
Two replicate tows, each of $60 \mathrm{~min}$ bottom duration at an average speed of 2.3 knots (a linear distance of approximately $4.2 \mathrm{~km}$ ) were completed in each depth strata at both locations at each time of sampling. The depth strata first sampled each month was randomly chosen, after which either the deeper or shallower depths were progressively sampled due to logistic considerations. It took approximately $8 \mathrm{~h}$ to complete all 6 tows at each location. For each replicate tow (sample), the catch from all 3 nets was combined and sorted, with all sillaginids identified and kept separate for biological sampling. The number and total weight of each sillaginid species captured in each sample was determined on-board the vessel.

\section{Processing of samples}

Whole catches or random sub-samples (100 to 200 individuals) of both species from each replicate tow were counted and measured (fork length [FL] nearest $1 \mathrm{~mm}$ ) for relative abundance and length composition. The total weight of the catch and subsample were weighed (nearest $5 \mathrm{~g}$ ). A further subsample of 30 individuals of each species from each replicate tow at each depth was retained on ice for processing in the laboratory. These fish were measured for FL, weighed (wet weight, nearest $0.1 \mathrm{~g}$ ) and had their gonads removed and weighed (blotted dry weight, nearest $0.1 \mathrm{~g}$ ) to calculate the gonadosomatic index (GSI) for each individual: GSI = (gonad weight / whole fish weight) $\times 100$. Each gonad was staged macroscopically following a development criteria based on oocyte size, colour and visibility adapted from Scott \& Pankhurst (1992): for males: I = immature, II = spermatogenic, III = partially spermiated, IV = fully spermiated, $V=$ spent; for females: $\mathrm{I}=\mathrm{im}-$ mature, II = immature/regressed, III = vitellogenic, IV = hydrated, $\mathrm{V}=$ ovulated, $\mathrm{VI}=$ spent. The gonads from a subset of females of both species were kept (preserved in $70 \%$ alcohol) to determine oocyte development and estimate potential batch fecundity (described below in 'Batch fecundity').

\section{Distributions and population structure}

General linear models (GLMs), assuming a Gaussian distribution with a log-transformed response variable, were used to test for differences in the relative abundance of each species across depths, seasons nested in years and years at Yamba, and across depths and seasons at Newcas- 
tle. Seasons were defined as summer (DecemberFebruary), autumn (March-May), winter (JuneAugust), spring (September-November) (allowing 2 full years between December 2005 and November 2007). Akaike information criteria (AIC) values were used to determine the most parsimonious model and probability tests ( $F$-tests at $\alpha=0.05$ ) were used to determine the influence of each term in each model by comparing change in deviance when each term was included or excluded from the model (Nelder \& Wedderburn 1972, Quinn \& Keough 2002). Tukey's post-hoc tests $(\alpha=0.05)$ were used to compare the different levels of each significant factor. Differences between depths in the length compositions of each species (pooled across seasons) at each location were tested using Kolmogorov-Smirnov (K-S) tests.

\section{Oocyte development}

Histological examination of a selection of preserved (70\% alcohol) Stage II, III and IV ovaries of both species was used to determine the development pattern of oocytes and to verify the macroscopic staging of females. Small sections were dissected from the middle of each ovary, treated in an automated tissue processor, with the resulting tissues embedded in paraffin wax and sectioned at $5 \mu \mathrm{m}$ thickness on a rotary microtome. Sections were deparaffinised, differentiated in acidified alcohol and stained in alcoholic eosin. Histological staging was based on the most advanced cohort of oocytes in each ovary section (West 1990).

Individual oocyte development was examined by determining the size distributions of oocytes in 10 random individuals of each species with Stage III ovaries. The entire ovary was blotted dry and weighed $(0.0001 \mathrm{~g})$, after which 3 replicate subsamples were taken from the mid-section of each ovary, blotted dry, weighed (0.0001 g) and placed in a sealed $70 \mathrm{ml}$ sample jar containing $70 \%$ alcohol solution. Each sub-sample was placed in a sonic bath (Unisonics FXP4) for a period no longer than $20 \mathrm{~min}$ to dislodge individual oocytes from surrounding connective tissue (Barnes et al. 2013). Oocytes from each sub-sample were transferred into a petri-dish, separated from each other, scanned and imaged at 1200 dpi resolution. Image analysis software (Image $\mathrm{J}$, Version 1.38) was used to determine the number and size of oocytes in each sub-sample. Sizefrequency plots of oocyte diameters were produced for each gonad.

\section{Length at maturity}

The estimated FL at which $50 \%\left(L_{50}\right)$ of males and females attained reproductive maturity was determined by fitting a logistic regression model using the binomial GLM function in R to the proportions of immature (Stages 1 and II) and mature (Stages III and above) fish in each $1 \mathrm{~mm}$ length class. The data used in these analyses was obtained during periods of high GSI. Differences between sexes and locations (and years for Yamba) in the estimated $L_{50}$ values of each species were tested using the 2-sampled $Z$ technique with $\alpha=0.05$ (Gunderson 1977).

\section{Reproductive period}

Temporal changes in mean male and female GSI values and proportions of fish with each macroscopic gonad stage (of individuals larger than the estimated mean length at maturity) were used to estimate the timing of spawning. Elevated GSI values and high proportions of fish with gonads staged III to VI were interpreted as probable spawning. The GLM procedures outlined above ('Distributions and population structure') were used to examine the influence of depths, seasons and, where relevant, year and seasons nested in year, on the proportions of mature individuals of each species present at each location. These GLMs assumed a binomial distribution, treating maturity as a binary response variable $(1=$ mature and $0=$ immature $)$, and used chi-squared $(\alpha=0.05)$ probability tests within the analysis of deviance tables.

\section{Batch fecundity}

The largest size class of oocytes (vitellogenic, $>0.30 \mathrm{~mm}$ for $S$. robusta and $>0.35 \mathrm{~mm}$ for $S$. flindersi) in mature, pre-spawning (Stage III) fishes were considered suitable for estimating potential batch fecundity (BF) (Hunter et al. 1985). The ovaries of up to 25 individuals from each species collected mid-spawning season at each location and in both years were examined. For each individual, the number of oocytes present was calculated using the same methodologies describe above ('Oocyte development') for investigating oocyte size-frequency distributions. Potential BF was estimated by scaling the number of oocytes present within the weighed ovarian subsample to the total preserved weight of the ovary. Log-linear models were used to describe relationships between estimated BF and FL and ANCOVA were used to test 
whether BF for each species differed according to location and FL.

\section{RESULTS}

\section{Relative abundance}

The GLMs showed that depth and season influenced the relative abundance of Sillago robusta and $S$. flindersi in different ways. Notably, S. robusta were most abundant in the shallow strata across most seasons at Yamba and Newcastle (Tukey's HSD tests: $\mathrm{p}<0.05$, Fig. 2), whereas, $S$. flindersi were consistently most abundant in the mid-depth strata across all seasons at Yamba (for which data were combined across years) and at Newcastle (Tukey's HSD tests:
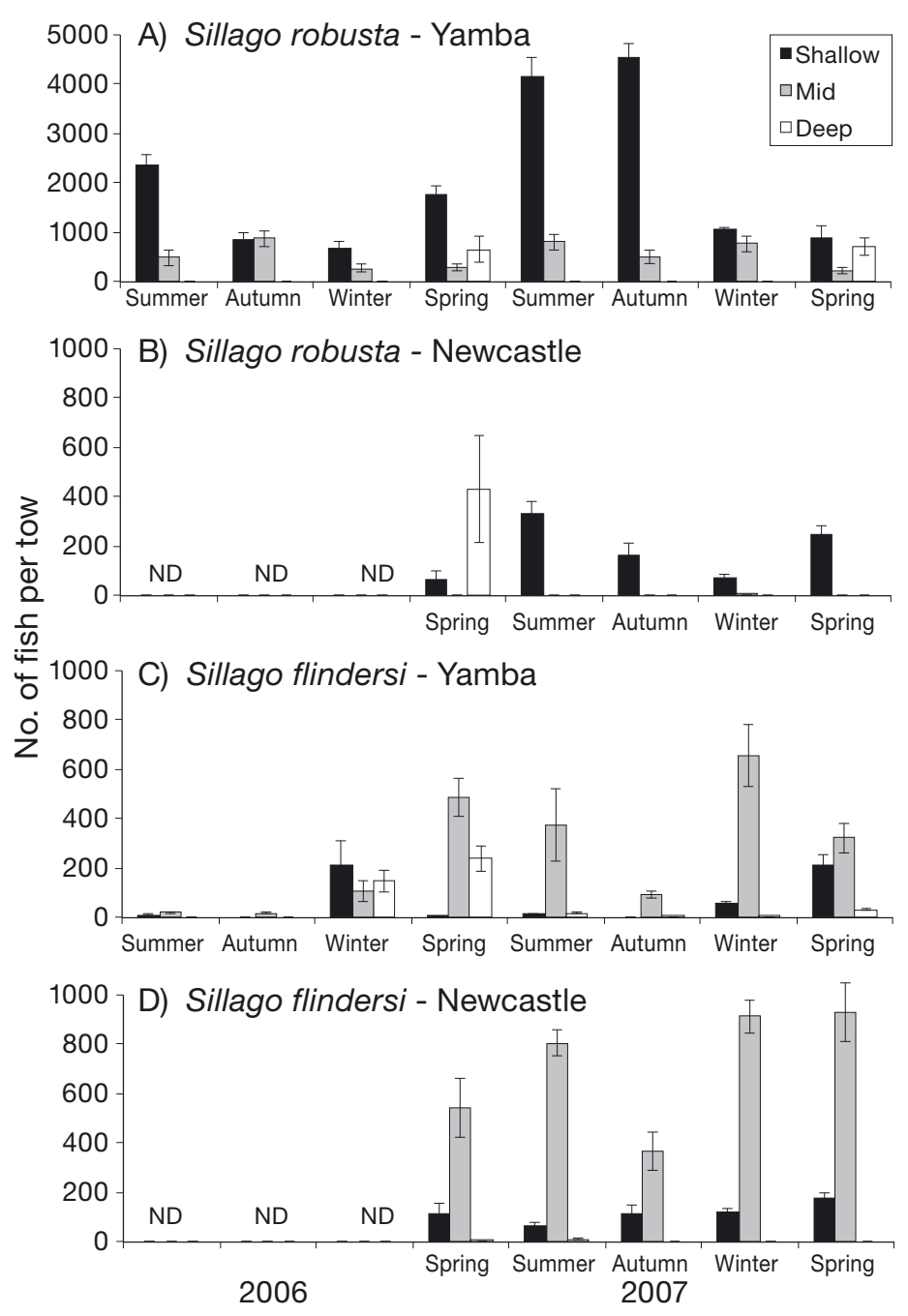

Fig. 2. Mean $( \pm \mathrm{SE})$ number of Sillago robusta and $S$. flindersi caught per tow in the shallow, mid and deep depth strata in each season at Yamba and Newcastle. ND: no data $\mathrm{p}<0.05$, Fig. 2). Neither species was consistently caught in large numbers in the deep strata, with $S$. robusta only found deep in spring, and $S$. flindersi only in spring and winter at Yamba.

Seasonal changes in the relative abundance of each species at each location were inconsistent and dependent on depth and year (where relevant). For example, abundances of $S$. robusta at Yamba (data combined across depths) did not show any significant differences between seasons in 2006, whereas they were significantly greater in summer and autumn in 2007 (Tukey's HSD tests: p < 0.05, Fig. 2). At Newcastle, abundances of this species only varied between seasons in the shallow strata, where they were significantly greater in summer compared to winter (Tukey's HSD test: $\mathrm{p}<0.05$, Fig. 2). In contrast, abundances of $S$. flindersi at Yamba (data combined across years and depths) were greatest in winter and spring (Tukey's HSD test: $p<0.05$, Fig. 2), whereas at Newcastle they were significantly lowest in autumn (Tukey's HSD test: $\mathrm{p}<0.05$, Fig. 2).

\section{Population structure}

The length compositions of samples of each species differed significantly according to depth and location (multiple K-S tests, $\mathrm{p}<0.05$ in all cases). Despite this, some general patterns were evident; notably a similar length range of $S$. robusta was present across all depth strata within each year at Yamba, and in the shallow and deep strata at Newcastle (Fig. 3). A cohort of small-sized ( $<10 \mathrm{~cm}$ FL) S. robusta was present in the shallow and mid-depth at Yamba in 2006 but not in 2007. For S. flindersi, a cohort of smallersized $(<13 \mathrm{~cm}$ FL) individuals predominated the shallow strata at both locations, whereas the mid and deep strata primarily contained individuals $>13 \mathrm{~cm}$ FL (Fig. 3). This later length cohort was also prominent in the shallow strata at Yamba in 2007.

\section{Oocyte development}

Both species displayed a similar pattern of ovarian development. Stage II ovaries contained unyolked oocytes of a variety of sizes, whereas Stage III ovaries contained a mixture of unyolked oocytes, partially yolked oocytes and oocytes that were in an advanced yolk stage of development (Fig. 4). The diameter sizes of this latter cohort of oocytes ranged from 0.30 to $0.45 \mathrm{~mm}$ for $S$. robusta and 0.35 to $0.50 \mathrm{~mm}$ for $S$. flindersi (Fig. 5). This suggested that $S$. flindersi 
A) Sillago robusta
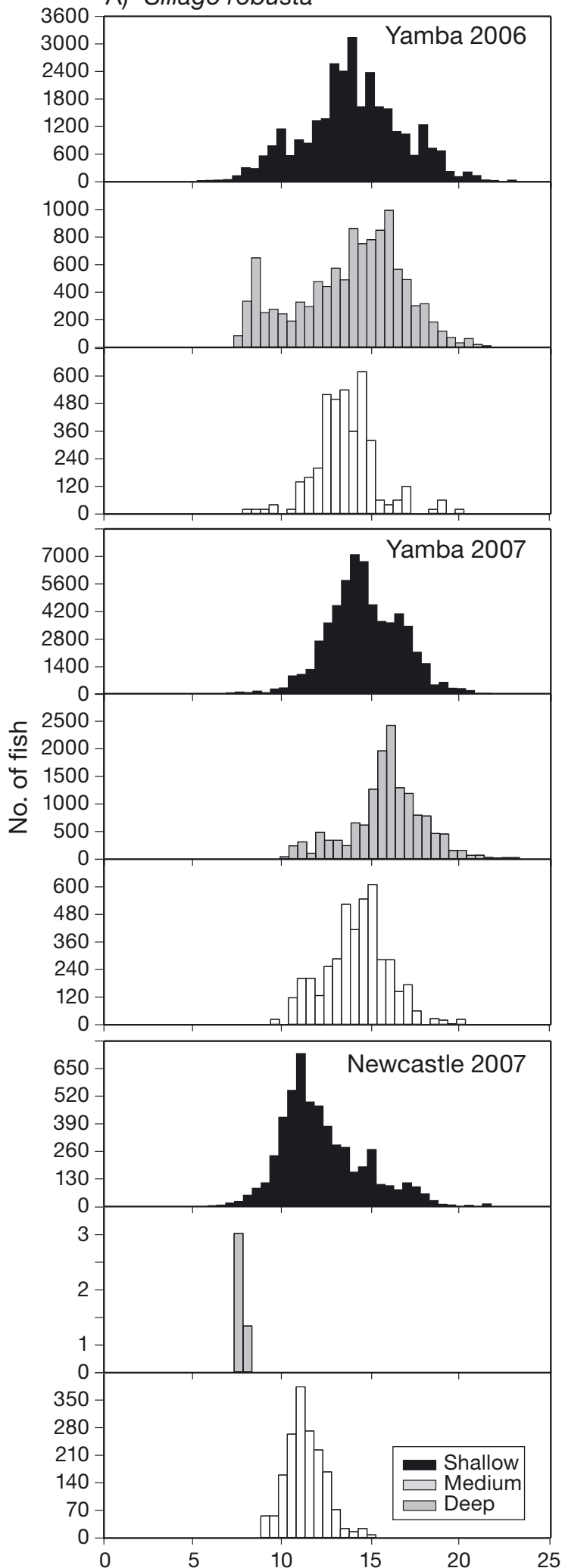

B) Sillago flindersi
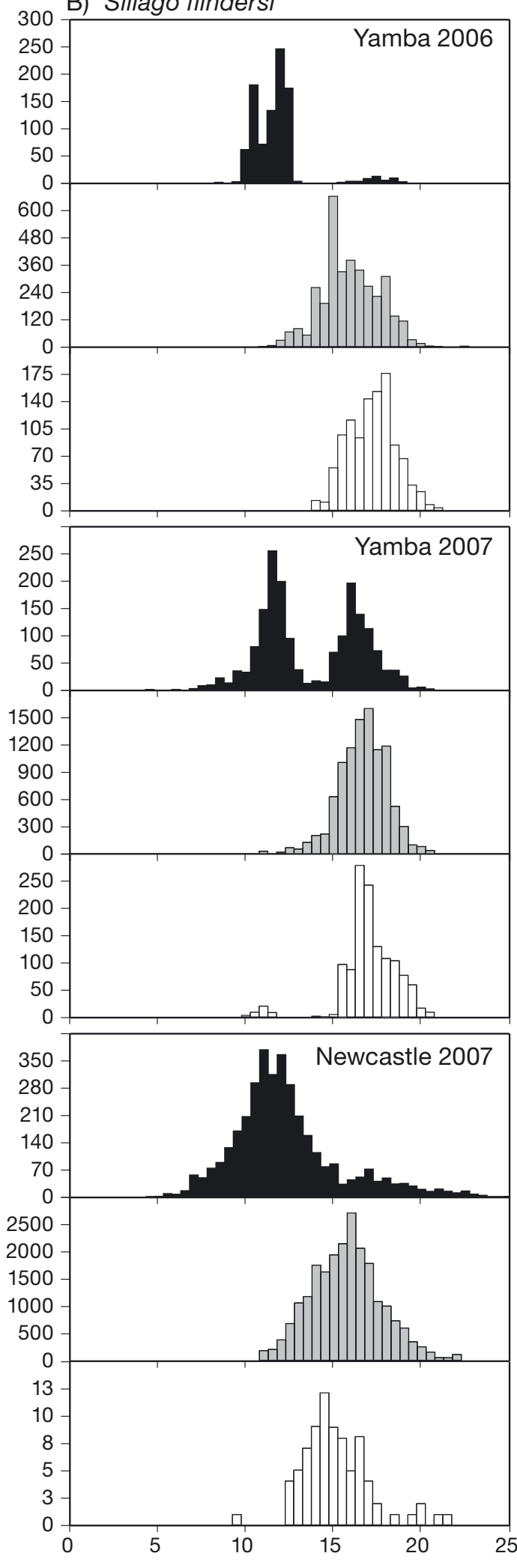

Fig. 3. Population length composition of Sillago robusta and S. flindersi in the shallow, mid and deep depth strata at Yamba and Newcastle. Data pooled across all sampling times for each year. Note different scales of $y$-axes 
A) Sillago robusta

Stage II

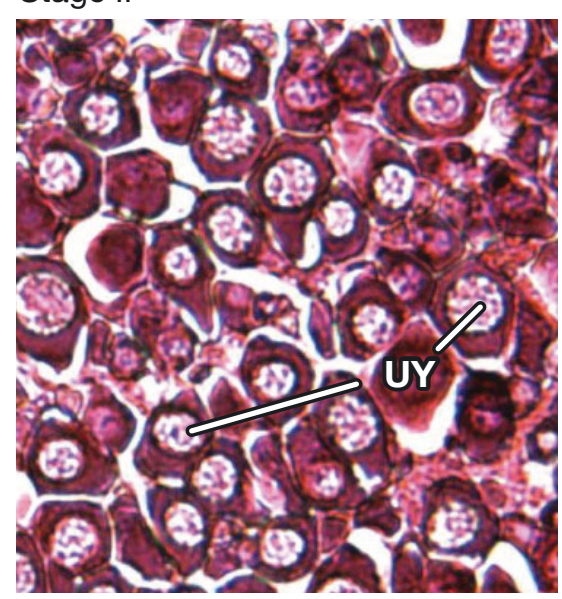

B) Sillago flindersi

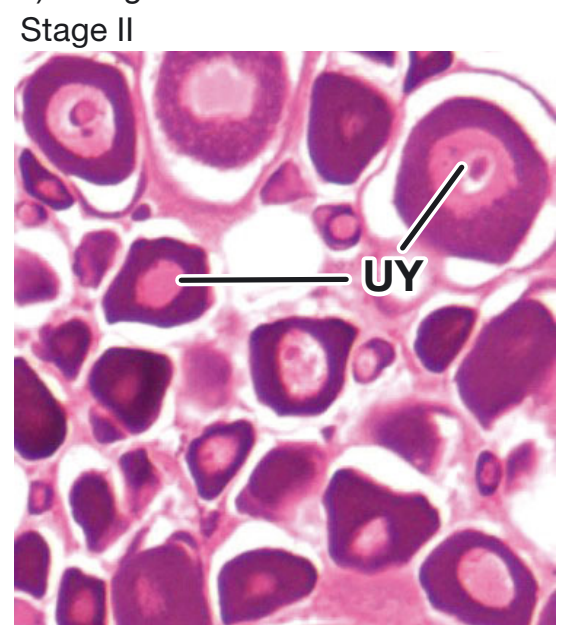

Stage III

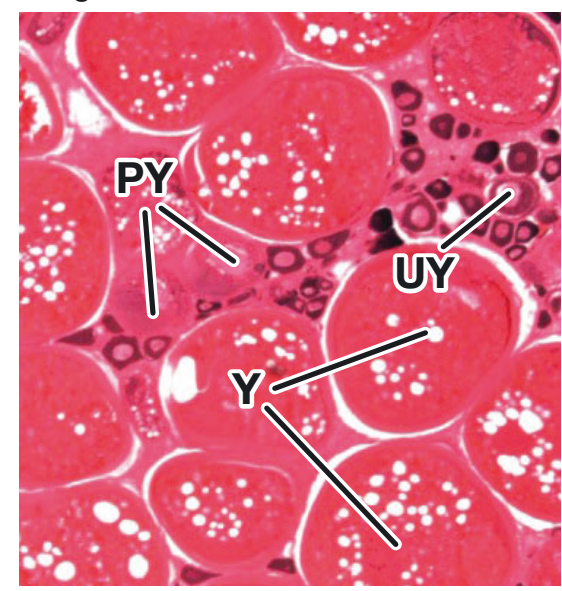

Stage IV

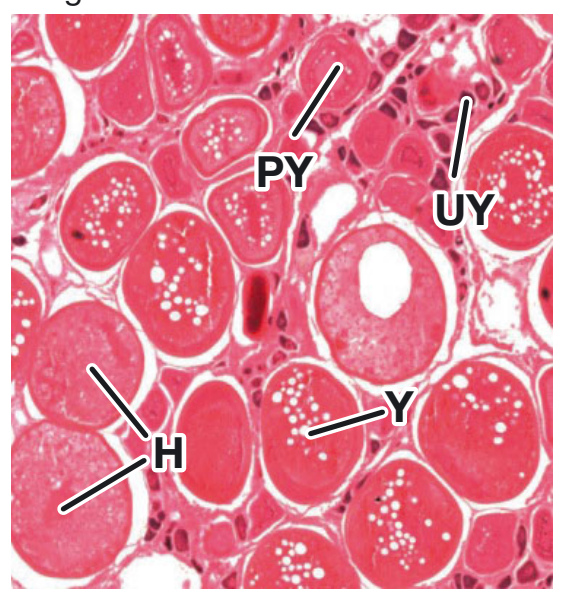

Stage III

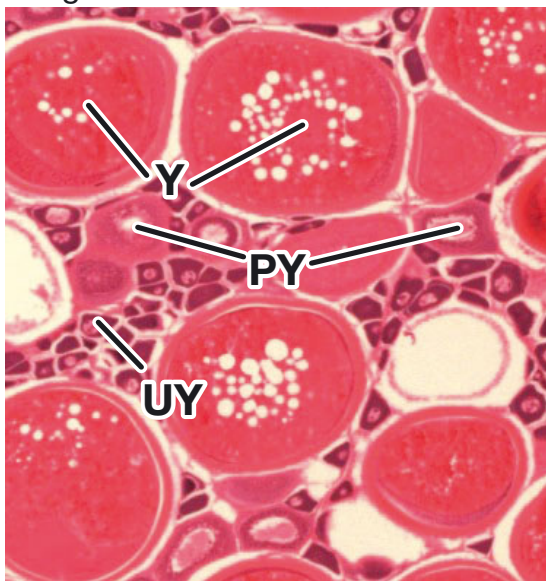

Stage IV

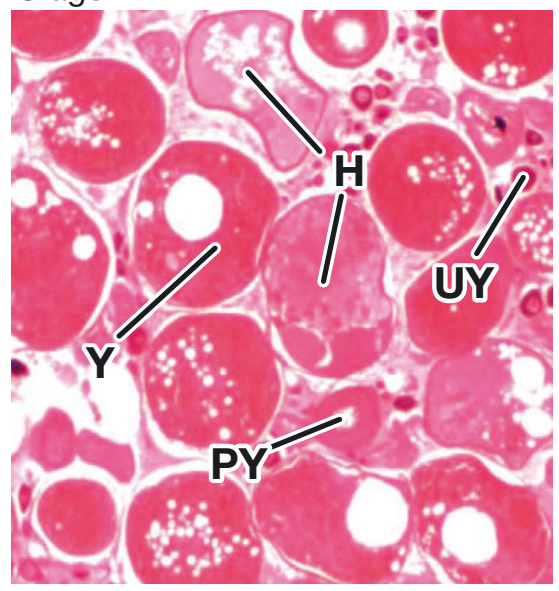

Fig. 4. Photos showing microscopic characteristics of ovary stages II, III and IV for Sillago robusta and S. flindersi. Stage II: immature ovary containing developing unyolked (UY) ooctyes, Stage III: mature ovary containing unyolked oocytes, partially yolked (PY) oocytes and advanced yolk (Y) stage oocytes, Stage IV: mature ovary containing ooctyes in all other stages of development as well as hydrated $(\mathrm{H})$ oocytes

might have produced larger eggs than S. robusta. Stage IV ovaries contained hydrated oocytes as well as oocytes in each of the previous stages of development (Fig. 4).

\section{Length at maturity}

There was no consistent effect of sex on length at maturity for either species. Notably, the $L_{50}$ was significantly ( $p<0.05)$ smaller for males than females of both species at both locations in 2007, but this was not the case in 2006 when the $L_{50}$ was significantly ( $\mathrm{p}<0.05)$ greater for male than for female $S$. robusta and there was no significant $(\mathrm{p}>0.05)$ difference between sexes for $S$. flindersi (Fig. 6). Evidence of spatial interactions in length at maturity was also apparent, with the $L_{50}$ of $S$. robusta being significantly $(\mathrm{p}<0.05)$ smaller at Newcastle for both sexes (Fig. 6). Significant spatial difference of length at maturity was also observed for female $S$. flindersi, which was greatest at Newcastle ( $<0.05)$, but not for males $(p>0.05)$. Males displayed temporal variations, with the $L_{50}$ being significantly $(\mathrm{p}<0.05)$ larger for both species at Yamba in 2006.

The estimated $L_{50}$ values for male and female $S$. robusta ranged from 12.84 to $15.35 \mathrm{~cm}$ FL and from 14.08 to $14.83 \mathrm{~cm} \mathrm{FL}$, respectively (Fig. 6). Similarly, the estimated $L_{50}$ values for male and female $S$. flindersi ranged from 13.27 to $13.96 \mathrm{~cm}$ FL and from 13.88 to $14.87 \mathrm{~cm} \mathrm{FL}$, respectively. The observed smallest mature male and female $S$. robusta was 11.3 and 
A) Sillago robusta

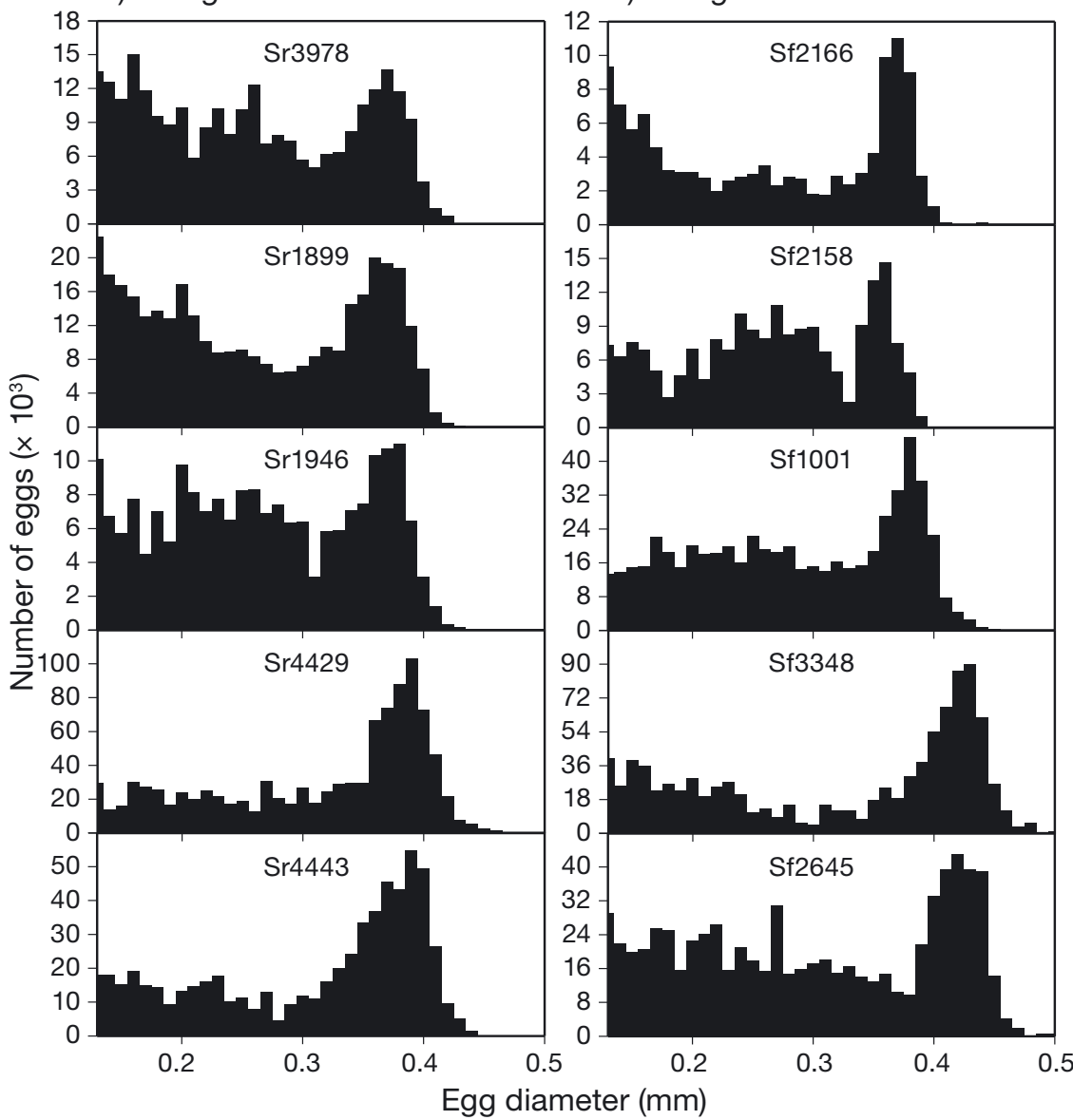

Fig. 5. Size distributions of oocytes in 5 individual Stage IV ovaries of Sillago robusta and $S$. flindersi. Numeric code refers to individual sample. Note different scales of $y$-axes

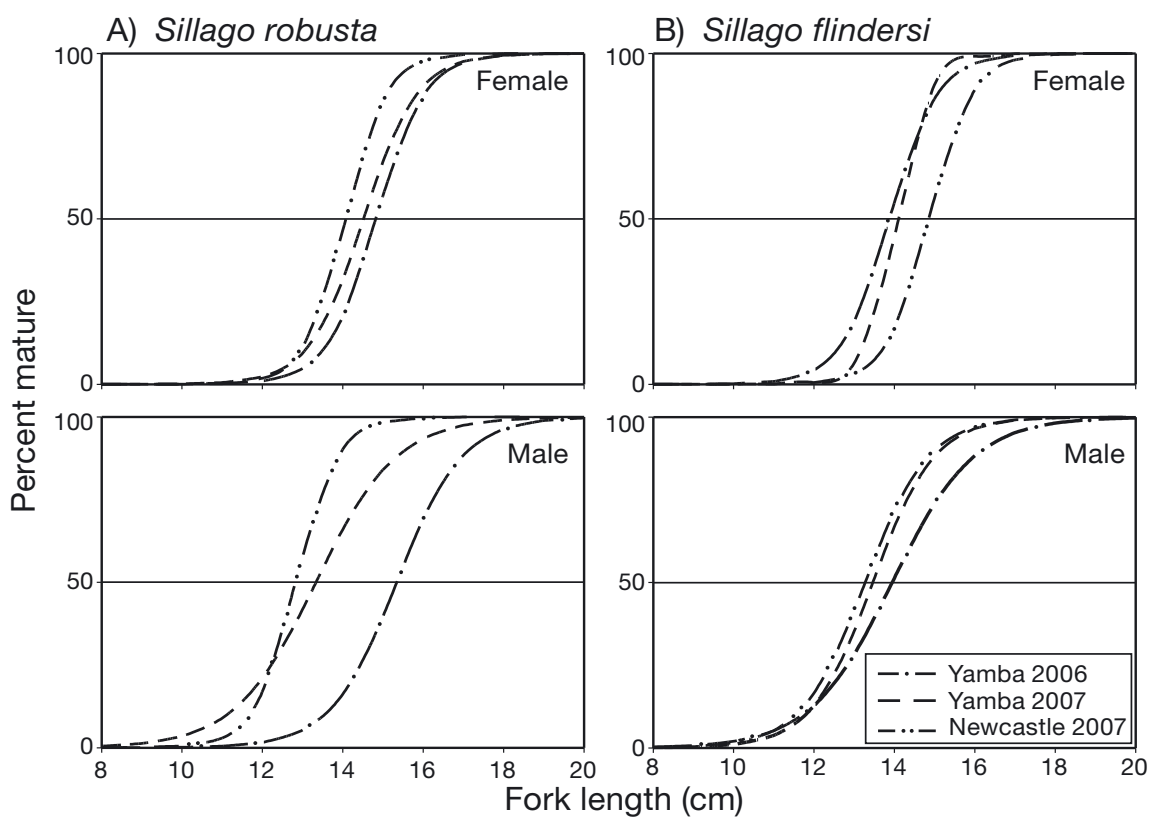

Fig. 6. Estimated maturity ogives of female and male Sillago robusta and S. flindersi at Yamba and Newcastle. Data combined across depth strata
$13.0 \mathrm{~cm}$ FL at Yamba and 11.4 and $12.5 \mathrm{~cm}$ FL at Newcastle, respectively. Likewise, the observed smallest mature male and female $S$. flindersi was 11.1 and $11.6 \mathrm{~cm}$ FL at Yamba and 11.0 and $13.0 \mathrm{~cm}$ FL at Newcastle, respectively.

\section{Spawning}

The macroscopic staging of gonads and changes in mean GSI values indicated both species potentially spawned year-round at both locations. Female and male $S$. robusta and $S$. flindersi with mature gonads (Stage III and higher) were present each month at Yamba (except June 2007 for $S$. flindersi) and most months at Newcastle (Fig. 7). Further, for both species ovaries containing hydrated eggs (Stage IV) were collected across most months at Yamba, although few were observed at Newcastle. There was also no consistent pattern for either species as to the months when particular gonad stages (mature/immature) were most or least prevalent. Nevertheless, for $S$. robusta a greater proportion of Stage I individuals were present in 2006 than 2007 at Yamba (Fig. 7)

The mean GSI values of female and male $S$. robusta at Yamba displayed similar trends through time and were generally lowest in late autumn and winter (April to July in 2006 and May to July in 2007). Mean GSI values tended to be highest between September and March in both years, suggesting that potentially a greater proportion of individuals spawn throughout the austral spring and summer (Fig. 8). There was no evidence of any such trend for this species at Newcastle where mean GSI values were relatively high between April and October. The maximum mean $( \pm \mathrm{SE})$ monthly GSI for female and male $S$. robusta was $2.86 \pm$ 0.12 and $2.55 \pm 0.23$ at Yamba and $3.27 \pm 0.82$ and $1.85 \pm 0.19$ at New- 


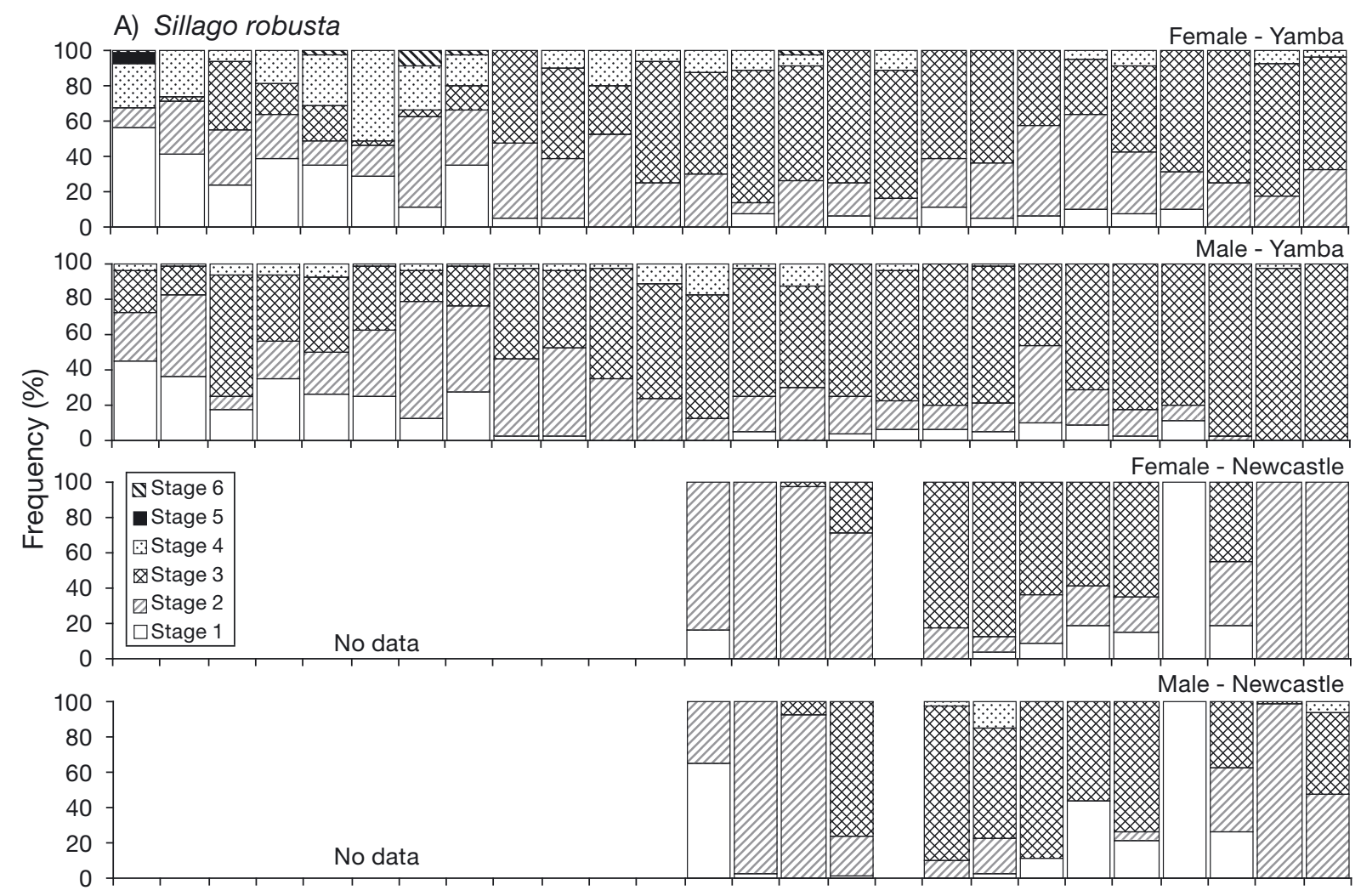

B) Sillago flindersi
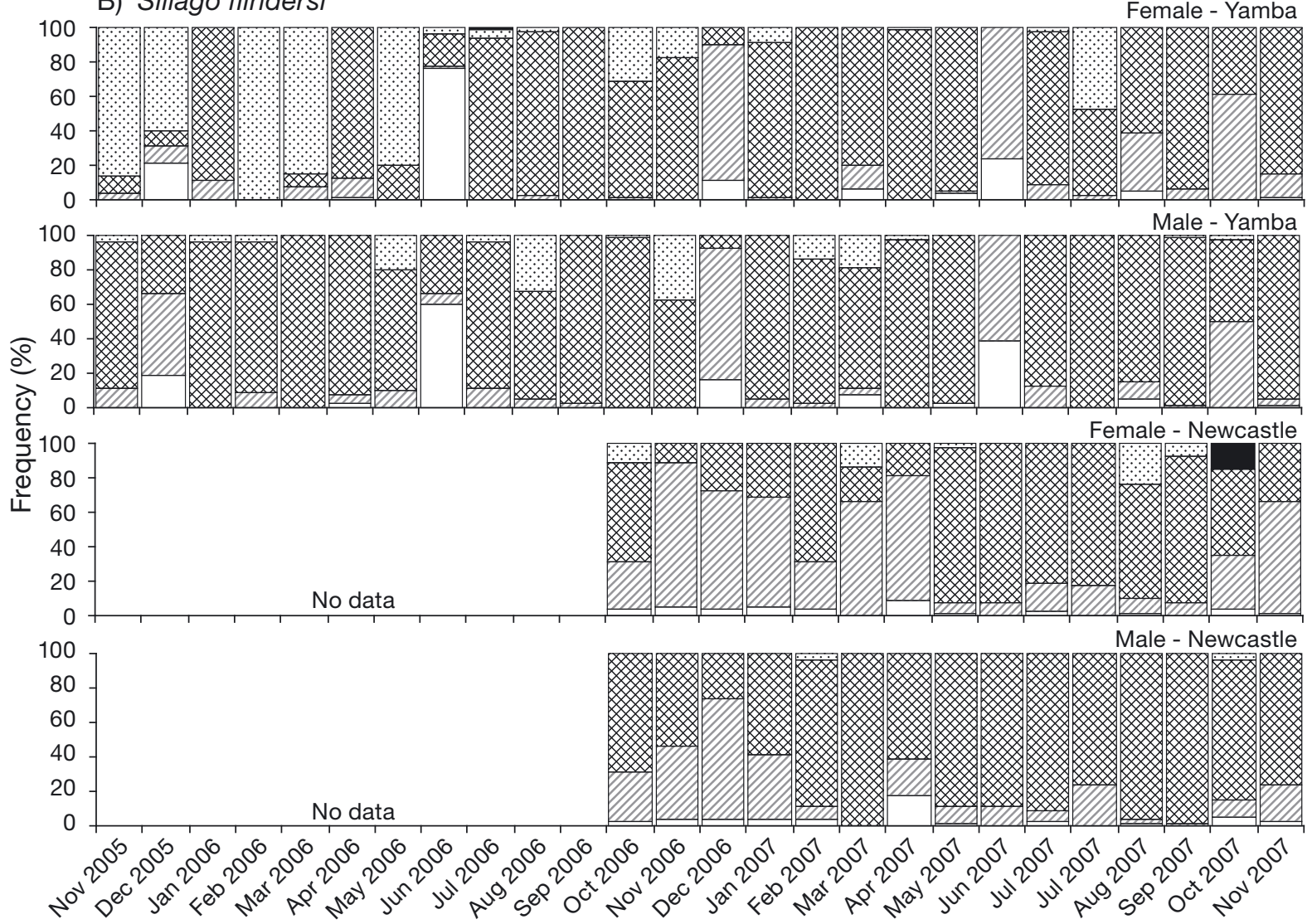

Fig. 7. Frequency of different macroscopically staged ovaries and testis of Sillago robusta and S. flindersi at Yamba and Newcastle. Data combined across depth strata 


\section{A) Sillago robusta}

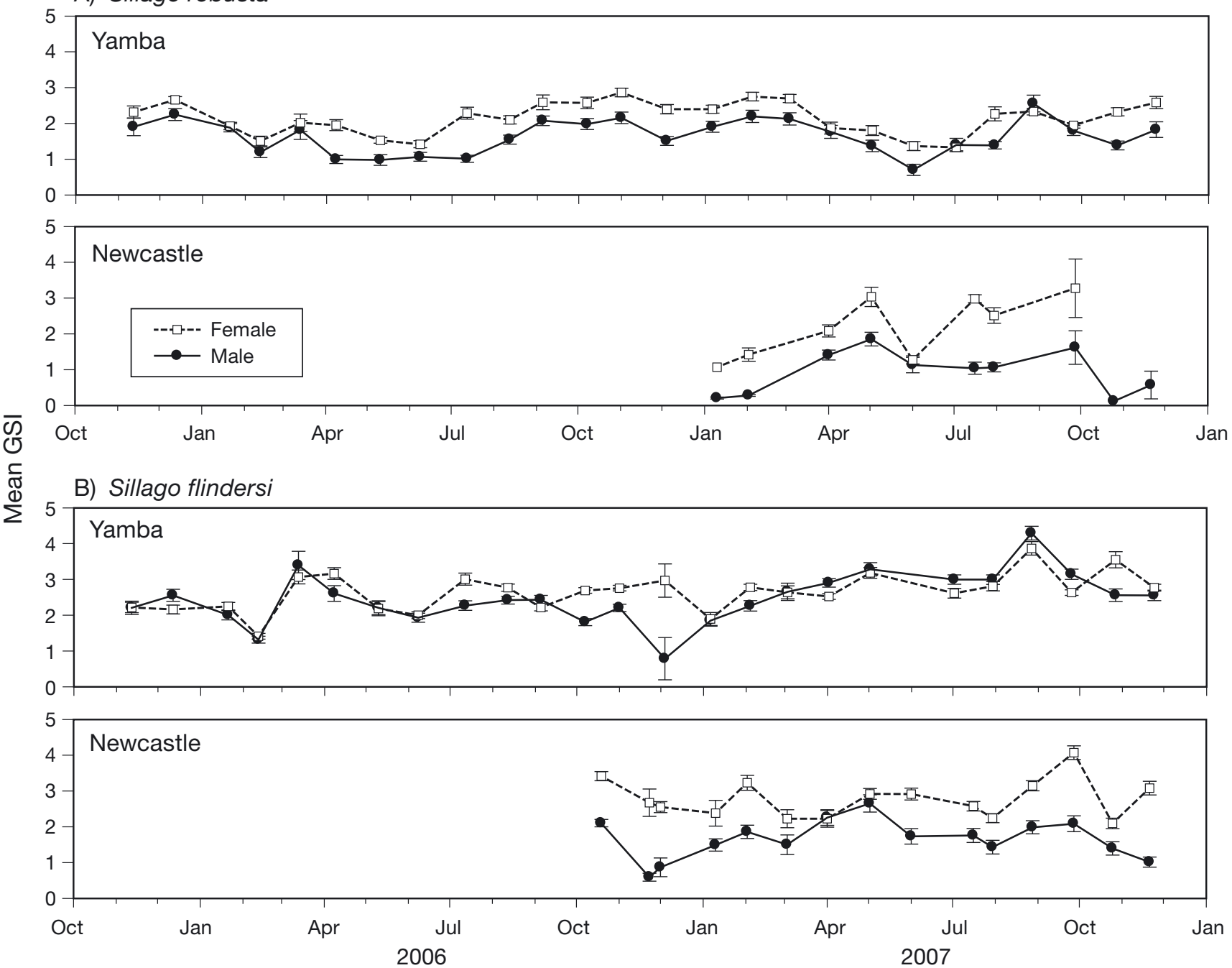

Fig. 8. Monthly variation in mean $( \pm \mathrm{SE})$ GSI of female and male Sillago robusta and $S$. flindersi at Yamba and Newcastle. Data combined across depth strata

castle, respectively. The mean GSI values of male and female $S$. flindersi remained relatively stable, displaying no seasonality throughout sampling at either location (Fig. 8). The maximum mean $( \pm \mathrm{SE})$ monthly GSI for female (male) $S$. flindersi was $3.87 \pm$ 0.18 and $4.29 \pm 0.19$ at Yamba and $4.07 \pm 0.19$ and $2.65 \pm 0.24$ at Newcastle, respectively.

For both species, the effect of year could not be tested due to significant depth $\times$ season (nested in year) and depth $\times$ year interactions. The maturity data collected from Yamba were therefore analysed in separate GLMs for the 2 years. The GLMs identified that a greater proportion of mature $S$. robusta occurred in the mid compared to the shallow strata in summer, winter and spring of 2006 and in summer, autumn and spring of 2007 at Yamba (Tukey's HSD test: $p<0.05$, Fig. 9; note that, for both years, this species was only caught in the deep strata dur- ing spring). In contrast, the significant depth-related effect in the GLM reflected a predominance of mature fish in the shallow strata compared to the deep strata at Newcastle (GLM: p (>Chi) < 0.05, Fig. 9; but note that this species was primarily only caught in the shallow strata and very few were caught in the mid strata irrespective of season). A significantly greater proportion of mature $S$. flindersi occurred in the mid and deep strata compared to the shallow strata across most seasons in both years at Yamba (Tukey's HSD test: $p<0.05$, Fig. 9). At Newcastle, the greatest proportion of mature $S$. flindersi occurred in the mid strata in winter and autumn (Tukey's HSD test: $\mathrm{p}<0.05$, Fig. 9; note that no $S$. flindersi were captured in the deep strata during these seasons) but in the deep strata in spring 2006 and summer 2007 (Tukey's HSD test: $\mathrm{p}<0.05$, Fig. 9). 


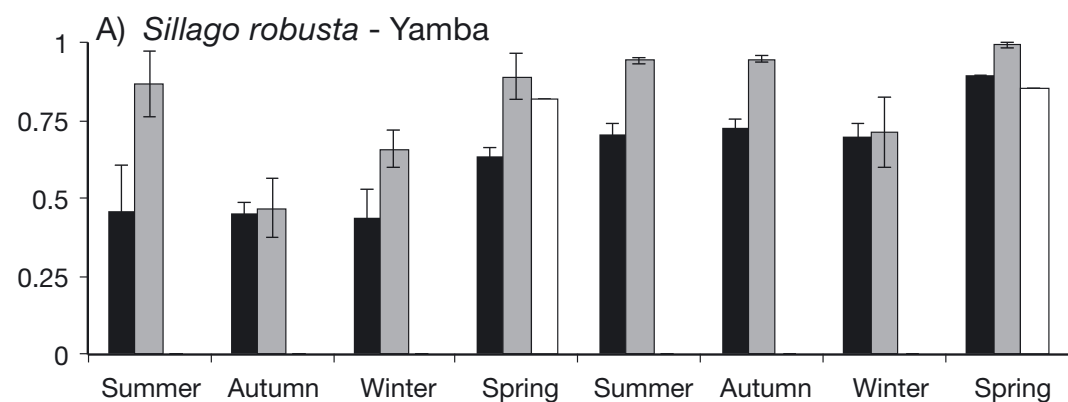

B) Sillago robusta - Newcastle
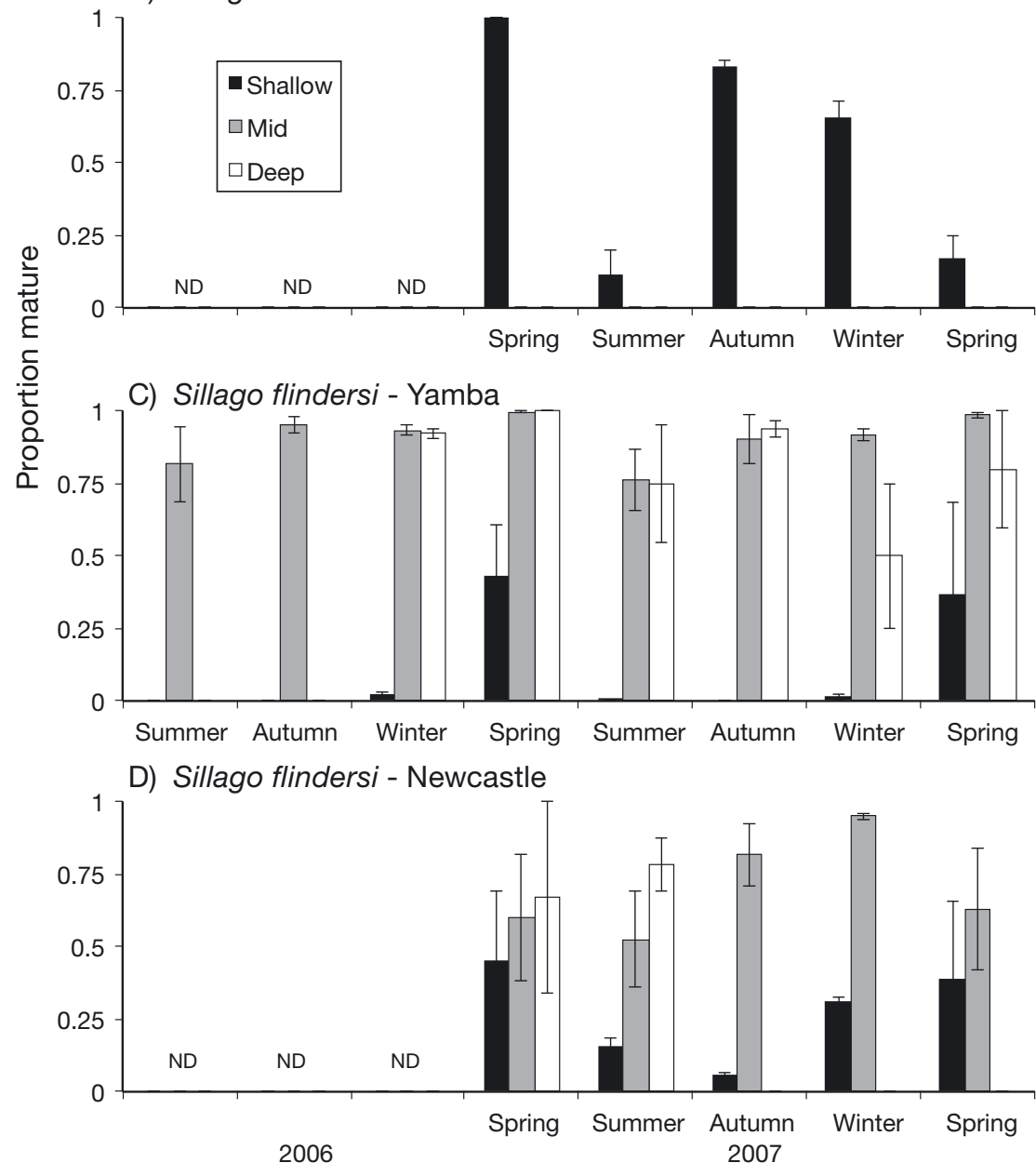

Fig. 9. Mean $( \pm \mathrm{SE})$ proportion of mature Sillago robusta and $S$. flindersi in the shallow, mid and deep depth strata in each season at Yamba and Newcastle. ND: no data

\section{Batch fecundity}

There was no significant difference between locations in the relationship between estimated BF and FL for either species (ANCOVA, $p>0.05$ in all cases), so data were combined across locations for each species. Estimated BF of both species significantly increased with FL ( $p<0.001$ in both cases); the log-linear rela- tionship $[\log (\mathrm{BF})=\log (\mathrm{a})+\mathrm{b} \times \log (\mathrm{FL})]$ was: $\log (a)=-3.0787, b=4.9280, \mathrm{r}^{2}=$ $0.6921, \mathrm{n}=25$ for $S$. robusta and $\log (a)=$ $-5.2534, \mathrm{~b}=5.5159, \mathrm{r}^{2}=0.7524, \mathrm{n}=24$ for $S$. flindersi. Estimated BF ranged from 7048 to 284755 eggs for $S$. robusta measuring 13.0 to $21.6 \mathrm{~cm} \mathrm{FL}$, and from 6773 to 256100 for $S$. flindersi measuring 13.1 to $23.4 \mathrm{~cm}$ FL. These data indicated that at a given FL, fecundity was greater in $S$. robusta than in $S$. flindersi.

\section{DISCUSSION \\ Population structuring and habitat partitioning}

Spatial and temporal structuring of eastern populations of Sillago robusta and $S$. flindersi was evident along a number of gradients suggesting possible partitioning of resources similar to other sympatric Sillaginidae (Hyndes et al. 1996a,b, 1997) and teleost families (Ross 1977, Genner et al. 1999, Barnes et al. in press). In general, $S$. robusta was more prevalent in the shallow strata whereas $S$. flindersi mostly occurred in the mid strata, while neither species consistently utilised the deep strata. Depth stratification of sillaginid and teleost populations and assemblages is widespread (Werner et al. 1977, Hyndes et al. 1999, Labropoulou et al. 2008, Gray et al. 2011).

The population length structure of $S$. robusta was similar across all depth strata, which is concordant with western populations of the species (Hyndes \& Potter 1996). In contrast, smaller and immature $S$. flindersi were more prominent in the shallow strata compared to the mid and deep strata, which were dominated by larger (mature) individuals. These data support the 'smaller-shallower' phenomena (Middleton \& Musick 1986, Stefanescu et al. 1992 ) and suggest that $S$. flindersi uses the shallow strata as a nursery area and then moves to deeper waters with growth and maturity. This is synonymous with the hypothesised life history of other Sillaginidae, including coastal $S$. bassensis and $S$. vittata (Hyndes \& Potter 1996, Hyndes et al. 1996b) and estuarine S. ciliata and S. maculata (Weng 1986, 
Burchmore et al. 1988). Depth-related ontogenetic shifts in distribution are common among teleosts (Macpherson \& Duarte 1991, Methratta \& Link 2007, Labropoulou et al. 2008), with shallow waters hypothesised to provide more food and greater protection of juveniles from predators (Ryer et al. 2010). Such stratification is also a potential mechanism to reduce intra- and interspecific competition and aid broadscale partitioning of resources among co-occurring species (Hyndes \& Potter 1996, 1997). In the present study, the shallow-water preference of small $S$. flindersi placed them directly in the preferred habitat of $S$. robusta. It is conceivable that a dietary mechanism ensured the smaller $S$. flindersi individuals were not competitively disadvantaged (Hyndes et al. 1997, Barnes et al. 2011). Alternatively, necessary resources in the shallow strata may not have been limited, reducing the need for species stratification.

\section{Spawning}

The data presented here indicate that $S$. robusta and $S$. flindersi are income-spawners (McBride et al. 2013), yet each species may have evolved slightly different reproductive strategies to deal with the dynamic coastal environment they inhabit. Despite neither species investing greatly in reproduction (low GSI values of females and males), the larger-growing $S$. flindersi generally displayed higher GSI ratios, suggesting it invests more energy into gonad production than $S$. robusta. Comparable differences in reproductive investment between other co-occurring Sillaginidae have been observed (Hyndes \& Potter 1996). Further, our data suggest that $S$. flindersi produced fewer (at any given length) but potentially larger eggs than $S$. robusta. We could not ascertain here, however, the effects of such trade-offs between the potential quality and quantity of larvae produced (Duarte \& Alcaraz 1989) on the reproductive success and population replenishment of either species.

Despite these apparent differences, the ovaries of mature $S$. robusta and $S$. flindersi contained oocytes of multiple sizes and developmental stages, indicating their potential to spawn several times within a given 'spawning' period (De Vlaming 1983, Hunter \& Macewicz 1985, West 1990). This concurs with other sillaginids (Lee \& Hirano 1985, Hyndes \& Potter 1996, Fowler et al. 1999, Kendall \& Gray 2009), adding further support to the hypothesis that the Sillaginidae are multiple-batch spawners. This spawning strategy is widespread among teleosts (Sarre \& Potter 1999, Walsh et al. 2011, Gray et al. 2012), allowing individuals to maximize the number of eggs produced over a particular period (Burt et al. 1988, McBride at al. 2013).

Mature individuals of both species could potentially spawn over extended periods. Fowler et al. (1999) estimated that individual Sillaginodes punctata spawned at least 20 times throughout their 3 mo spawning period. We could not determine the frequency and number of times an individual of either species may have released eggs throughout any given period or throughout its life. Consequently, the total number of eggs that each individual produces each year (total fecundity) could not be estimated. Nevertheless, estimated batch fecundity in both species was positively related to fish length, indicating that reproductive output is potentially greater in larger individuals, as in most teleosts (Parker 1992). Having a greater abundance of larger (and presumably older) individuals could theoretically increase the collective reproductive potential of teleost populations, and enhance larval survival (Berkeley et al. 2004). Fishing gears that allow a greater proportion of fish to reach larger sizes could enhance the reproductive potential and sustainability of these sillaginid populations.

The potential year-round spawning of $S$. robusta and $S$. flindersi, as evidenced by changes in GSI values and the macro- and microscopic staging of gonads, is further corroborated by the occurrence of pelagic larvae of both species year-round in coastal waters off eastern Australia (Gray \& Miskiewicz 2000). This extended period of spawning is in contrast to western populations of $S$. robusta occurring at similar latitudes that spawn between December and March (Hyndes \& Potter 1996). Our data indicate, however, that a greater proportion of the eastern populations of $S$. robusta spawn between September and March. This predominate spring-summer spawning pattern is also true for the east-Australian estuarinebased sillaginids $S$. ciliatia and S. maculata (Morton 1985, Burchmore et al. 1988, Kendall \& Gray 2009) as well as a suite of other coastal sillaginids, including S. burrus, S. bassensis, S. schomburgkii, S. vittata and S. aeolus (Hyndes \& Potter 1996, 1997, Hyndes et al. 1996b, Rahman \& Tachihara 2005a). Periods of increasing water temperature and photoperiod may potentially trigger reproductive development and spawning in these species (Hyndes \& Potter 1996). In contrast, similar proportions of the $S$. flindersi populations sampled here spawned year-round, indicating that changes in water temperature and photoperiod were not the primary cue to trigger reproductive development and spawning in this species.

The extended spawning of eastern populations of $S$. robusta and $S$. flindersi and the potential ability of 
individuals to spawn multiple times in a spawning season is probably an adaptation to the stochastic and dynamic oceanography of this coastal region. This strategy should enhance the probability of successful survival and recruitment of some eggs and larvae (Lambert \& Ware 1984, Lowerre-Barbieri et al. 2011, McBride et al. 2013) and could also be a life history tactic to enhance dispersal of young as well as maintaining genetic connectivity among populations along eastern Australia, as suggested for other coastal boundary current inhabitants (Hare \& Cowen 1993, Gray et al. 2012). Further, spawning by species in the depths examined here may be advantageous to maximising alongshore dispersal and subsequent retention of eggs and larvae in shelf waters by the East Australian Current (Roughan et al. 2011).

The observed prolonged reproductive period of both species in eastern Australia compared to other sillaginid populations could also potentially be a response to high levels of fishing-related mortalities in these particular populations. High exploitation rates can impact teleost reproductive strategies, including lowering sizes and ages at maturity, increasing egg production and spawning frequency, and lengthening spawning periods (Rochet 1998, Sharpe \& Hendry 2009, Wright \& Trippel 2009). The sillaginid populations examined here have been commercially harvested for over $100 \mathrm{yr}$, with catches over the past $20 \mathrm{yr}$ exceeding $2000 \mathrm{t}$ per annum. These levels of exploitation could potentially be sufficient to have already caused modifications of reproductive strategies of these populations.

Despite the differences outlined above, spawning of $S$. robusta and $S$. flindersi overlapped greatly in space and time. This is common among closely related teleosts (Muthiga 2003, Park et al. 2006, Tomaiuolo et al. 2007) and may be related to similar evolutionary histories and environmental requirements (Mercier \& Hamel 2010). Thus, there was no specific evidence of large-scale reproductive isolation between these sillaginid species (Wellenreuther \& Clements 2007). Reproductive isolation can occur between sympatric species over much finer spatial and temporal scales than examined here (Colin \& Clavijo 1988, Colin \& Bell 1991, Sancho et al. 2000), which could be further explored in these species.

\section{Maturity and fishery considerations}

The estimated $L_{50}$ for both species were mostly smaller for males compared to females, which is in general agreement with other sillaginids (Kendall \&
Gray 2009). Length at maturity of $S$. robusta as determined here was greater by about 1.5 to $2.0 \mathrm{~cm}$ than for western populations (Hyndes \& Potter 1996). A plethora of biotic and abiotic factors, as well as anthropogenic influences (e.g. fishing) can potentially cause broad-scale variations in length (and age) at maturity among populations (Lassalle et al. 2008). Importantly, these data demonstrate the potential for intraspecific plasticity in life history characteristics among discrete populations of teleosts (Gust et al. 2002, Ruttenberg et al. 2005, Blanck \& Lamouroux 2007, Sala-Bozano \& Mariani 2011), emphasising the need for regional information of population demographics for fisheries assessment and management.

Significant spatial and temporal differences in the estimated $L_{50}$ of each species were also detected at the smaller regional scale examined here, with differences in parameter estimates between years being equal to between locations. Although such results could be artefacts of variations in sample composition, they demonstrate the potential limitations of such demographic information collected at one place and time (i.e. typical snapshot studies). Indeed, a lack of information of levels of variability in demographic parameters (including rates of growth and mortality) across a species distribution could confound biological-based fisheries assessments and management plans (Morgan \& Bowering 1997, Ruttenberg et al. 2005, Jakobsen et al. 2009).

Fisheries managers often set the retained legal lengths of fish at the $L_{50}$ to potentially allow $50 \%$ of individuals to spawn at least once prior to harvesting (King \& McFarlane 2003). Since eastern populations of $S$. robusta and $S$. flindersi are often caught together in large quantities as by-product by commercial trawlers targeting penaeid prawns, a common retained legal length of $14 \mathrm{~cm}$ FL $(\sim 15 \mathrm{~cm}$ total length) could be applied to these species in these fisheries if required. This length corresponds closely to the $50 \%$ length selection for these species in $35 \mathrm{~mm}$ square mesh cod-ends tested and recommended for use in the east Australian demersal penaeid trawl fisheries in which these species are an important by-product (Broadhurst et al. 2005, Graham et al. 2009, Macbeth et al. 2012). For other fisheries in which these sillaginids are the target species, having gears that specifically select fish $>L_{50}$ (e.g. $20 \mathrm{~cm}$ FL) could aid reproductive potential and resource sustainability. In high-volume multispecies trawl fisheries, it is often preferable to manage and regulate the sizes of fish retained by prescribing the selectivity of the fishing gears rather than enforce- 
ment of specific legal lengths, which can be logistically problematic for fisheries operators as well as compliance officers. Nevertheless, prior to introducing and mandating any specific fishing gears (or retained legal lengths for these sillaginid species) in any particular fishery, assessments of rates of survival of non-retained individuals in such fishing gears (Broadhurst et al. 2006, Coggins et al. 2007), as well as broader market and economic impacts need to be considered. Moreover, the potential effects on population reproductive output and resource sustainability of alternate management arrangements that protect larger (more fecund) fish, either by harvesting particular slot sizes (Gwinn et al. 2013) or provision of refuge (no-take) areas (Roberts et al. 2005) needs investigating.

Acknowledgements. This research was funded by the NSW Government and done in accordance with the NSW DPI Animal Care and Ethics Permit 2005/05 whilst the authors were located at the (now closed) Cronulla Fisheries Research Centre of Excellence. We thank Don Anderson (El Margo) and Bruce Korner (Little John) for their fishing expertise and assistance with sampling. Damian Young assisted with fieldwork and Caitlin Young, Justin McKinnon, Martin Jackson and Adam Welfare helped process samples in the laboratory and Jim Craig provided database management. Drs. Chris Walsh, Matt Ives and the journal referees provided constructive reviews of the draft manuscript.

\section{LITERATURE CITED}

Barnes LM, Leclerc M, Gray CA, Williamson JE (2011) Dietary niche differentiation of five sympatric species of Platycephalidae. Environ Biol Fish 90:429-441

Barnes LM, van der Meulen DE, Orchard BA, Gray CA (2013) Novel use of an ultrasonic cleaning device for fish reproductive studies. J Sea Res 76:222-226

Berkeley SA, Chapman C, Sogard SM (2004) Maternal age as a determinant of larval growth and survival in a marine fish, Sebastes melanops. Ecology 85:1258-1264

$>$ Blanck A, Lamouroux N (2007) Large-scale intraspecific variation in life-history traits of European freshwater fish. J Biogeogr 34:862-875

Broadhurst MK, Young DJ, Gray CA, Wooden MEL (2005) Improving selection in south eastern Australian whiting (Sillago spp.) trawls: effects of modifying the body, extension and codend. Scientia Mar 69:301-311

Broadhurst MK, Suuronen P, Hulme A (2006) Estimating collateral mortality from towed fishing gear. Fish Fish 7: 180-218

Burchmore JJ, Pollard DA, Middleton MJ, Bell JD, Pease BC (1988) Biology of four species of whiting (Pisces: Sillaginidae) in Botany Bay, NSW. Aust J Mar Freshw Res 39:709-727

Burt A, Kramer DL, Nakatsuru K, Spry C (1988) The tempo of reproduction in Hyphessobrycon pulchripinnis (Characidae), with a discussion on the biology of 'multiple spawning' in fishes. Environ Biol Fish 22:15-27

Butcher AR, Hagedoorn WL (2003) Age, growth and mortality estimates of stout whiting, Sillago robusta Stead (Sil- laginidae), from southern Queensland, Australia. Asian Fish Sci 16:215-228

Chen W, Almatar S, Bishop JM (2009) Spatial and temporal variability of fish assemblage in Kuwait Bay. Mar Biol 156:415-424

Cleland KW (1947) Studies on the economic biology of sand whiting (Sillago ciliata C. \& V.). Proc Linn Soc NSW 72: 215-228

> Coggins LG Jr, Catalano MJ, Allen MS, Pine WE III, Walters CJ (2007) Effects of cryptic mortality and the hidden costs of using length limits in fishery management. Fish Fish 8:196-210

> Colin PL, Bell LJ (1991) Aspects of the spawning of ladrid and scarid fishes (Pisces, Labroidei) at Enewetak-Atoll, Marshall Islands with notes on other families. Environ Biol Fish 31:229-260

Colin PL, Clavijo IE (1988) Spawning activity of fishes producing pelagic eggs on a shelf edge coral-reef, Southwestern Puerto-Rico. Bull Mar Sci 43:249-279

> Colloca F, Carpentieri P, Balestri E, Ardizzone G (2010) Food resource partitioning in a Mediterranean demersal fish assemblage: the effect of body size and niche width. Mar Biol 157:565-574

> Coulson PG, Hesp AS, Potter IC, Hall NG (2005) Comparisons between the biology of two co-occurring species of whiting (Sillaginidae) in a large marine embayment. Environ Biol Fish 73:125-139

De Vlaming VL (1983) Oocyte development patterns and hormonal involvements among teleosts. In: Rankin JC, Pitcher TJ, Duggan RT (eds) Control processes in fish physiology. Croom Helm, Beckenham, p 176-199

- Duarte cm, Alcaraz M (1989) To produce many small or few large eggs: a size-independent reproductive tactic of fish. Oecologia 80:401-404

Fowler AJ, Short DA (1996) Temporal variation in the early life-history characteristics of the King George whiting (Sillaginodes punctata) from analysis of otolith microstructure. Mar Freshw Res 47:809-818

Fowler AJ, McLeay L, Short DA (1999) Reproductive mode and spawning information based on gonad analysis for the King George whiting (Percoidei: Sillaginidae) from South Australia. Mar Freshw Res 50:1-14

$>$ Fowler AJ, McLeay L, Short DA (2000) Spatial variation in size and age structures and reproductive characteristics of the King George whiting (Percoidei: Sillaginidae) in South Australian waters. Mar Freshw Res 51:11-22

> Genner MJ, Turner GF, Hawkins SJ (1999) Foraging of rocky habitat cichlid fishes in Lake Malawi: coexistence through niche partitioning? Oecologia 121:283-292

> Graham KJ, Broadhurst MK, Millar RB (2009) Effects of codend circumference and twine diameter on selection in south-eastern Australian fish trawls. Fish Res 95:341-349

Gray CA, Kennelly SJ (2003) Catch characteristics of the commercial beach-seine fisheries in two Australian barrier estuaries. Fish Res 63:405-422

> Gray CA, Miskiewicz AG (2000) Larval fish assemblages in south-east Australian coastal waters: seasonal and spatial structure. Estuar Coast Shelf Sci 50:549-570

> Gray CA, Otway NM (1994) Spatial and temporal differences in the assemblages of demersal fishes on the inner continental shelf off Sydney, southeastern Australia. Aust J Mar Freshw Res 45:665-676

> Gray CA, Rotherham D, Johnson DJ (2011) Consistency of temporal and habitat-related differences among assemblages of fish in coastal lagoons. Estuar Coast Shelf Sci 95:401-414

Gray CA, Haddy JA, Fearman J, Barnes LM, Macbeth WG, 
Kendall BW (2012) Reproduction, growth and connectivity among populations of Girella tricuspidata (Pisces: Girellidae). Aquat Biol 16:53-68

Gunderson DR (1977) Population biology of pacific ocean perch, Sebastes alutus, stocks in the Washington-Queen Charlotte Sound region, and their response to fishing. Fish Bull 75:369-403

Gunn JS, Milward NE (1985) The food, feeding habits and feeding structures of the whiting species Sillago sihama (Forsskal) and Sillago analis Whitley from Townsville, North Queensland, Australia. J Fish Biol 26:411-427

Gust N, Choat JH, Ackerman JL (2002) Demographic plasticity in tropical reef fishes. Mar Biol 140:1039-1051

> Gwinn DC, Allen MS, Johnston FD, Brown P, Todd CR, Arlinghaus R (2013) Rethinking length-based fisheries regulations: the value of protecting old and large fish with harvest slots. Fish Fish. doi:10.1111/faf.12053

Hajisamae S, Yeesin P, Ibrahim S (2006) Feeding ecology of two sillaginid fishes and trophic interrelations with other co-existing species in the southern part of South China Sea. Environ Biol Fish 76:167-176

Hare JA, Cowen RK (1993) Ecological and evolutionary implications of the larval transport and reproductive strategy of bluefish Pomatomus saltatrix. Mar Ecol Prog Ser 98:1-16

Hunter JR, Macewicz BJ (1985) Measurement of spawning frequency in multiple spawning fishes. In: Lasker R (ed) An egg production method for estimating spawning biomass of pelagic fish: application to the northern anchovy, Engraulis mordax. US Dep Commerce, NOAA Tech Rep NMFS 36, Springfield, p 79-93

Hunter JR, Lo NCH, Leong RJH (1985) Batch fecundity in multiple spawning fishes. In: Lasker R (ed) An egg production method for estimating spawning biomass of pelagic fish: application to the northern anchovy, Engraulis mordax. US Dep Commerce, NOAA Tech Rep NMFS 36, Springfield, p 67-77

- Huyer A, Smith RL, Stabeno PJ, Church JA, White NJ (1988) Currents off south-eastern Australia: results from the Australian Coastal Experiment. Aust J Mar Freshw Res 39:245-288

Hyndes GA, Potter IC (1996) Comparisons between the age structures, growth and reproductive biology of two cooccurring sillaginids, Sillago robusta and S. bassensis, in temperate coastal waters of Australia. J Fish Biol 49:14-32

Hyndes GA, Potter IC (1997) Age, growth and reproduction of Sillago schomburgkii in south-western Australian nearshore waters and comparisons of life history styles of a suite of Sillago species. Environ Biol Fish 49:435-447

> Hyndes GA, Potter IC, Lenanton RCJ (1996a) Habitat partitioning by whiting species (Sillaginidae) in coastal waters. Environ Biol Fish 45:21-40

Hyndes GA, Potter IC, Hesp SA (1996b) Relationships between the movements, growth, age structures, and reproductive biology of the teleosts Sillago burrus and $S$. vittata in temperate marine waters. Mar Biol 126:549-558

Hyndes GA, Platell ME, Potter IC (1997) Relationships between diet and body size, mouth morphology, habitat and movements of six sillaginid species in coastal waters: implications for resource partitioning. Mar Biol 128: 585-598

Hyndes GA, Platell ME, Potter IC, Lenanton RCJ (1998) Age composition, growth, reproductive biology, and recruitment of King George whiting, Sillaginodes punctata, in coastal waters of south-western Australia. Fish Bull 96: 258-270

- Hyndes GA, Platell ME, Potter IC, Lenanton RCJ (1999)
Does the composition of the demersal fish assemblages in temperate coastal waters change with depth and undergo consistent seasonal changes? Mar Biol 134: $335-352$

Jakobsen T, Fogarty MJ, Megrey BA, Moksness E (2009) Fish reproductive biology; implications for assessment and management. Blackwell Publishing, Chichester

Kailola PJ, Williams MJ, Stewart PC, Reichelt RE, McNee A, Grieve C (1993). Australian Fisheries Resources. Bureau of Resource Sciences, Department of Primary Industry and Energy, and the Fisheries Research and Development Corporation, Canberra

Kemp J, Lyly J, Rowling K, Ward P (2012) Eastern school whiting Sillago flindersi. In: Flood M, Stobutzki I, Andrews J, Begg G and others (eds) Status of key Australian fish stocks reports 2012. Fisheries Research and Development Corporation, Canberra, p 391-395.

Kendall BW, Gray CA (2009) Reproduction, age and growth of Sillago maculata (Sillaginidae) in south-eastern Australia. J Appl Ichthyol 25:529-536

Kennelly SJ, Liggins GW, Broadhurst MK (1998) Retained and discarded bycatch from oceanic prawn trawling in New South Wales, Australia. Fish Res 36:217-236

King JR, McFarlane A (2003) Marine fish life history strategies: applications to fishery management. Fish Manag Ecol 10:249-264

> Labropoulou M, Damalas D, Papaconstantinou C (2008) Bathymetric trends in distribution and size of demersal fish species in the north Aegean Sea. J Nat Hist 42: 673-686

Lambert TC, Ware DM (1984) Reproductive strategies of demersal and pelagic spawning fish. Can J Fish Aquat Sci 41:1564-1569

> Lassalle G, Trancart T, Lambert P, Rochard E (2008) Latitudinal variations in age and size at maturity among allis shad Alosa alosa populations. J Fish Biol 73:1799-1809

Lee CS, Hirano R (1985) Effects of water temperature and photoperiod on the spawning cycle of the sand borer, Sillago sihama. Prog Fish-Cult 47:225-230

Lowerre-Barbieri SK, Ganias K, Saborido-Rey F, Murua H, Hunter JR (2011) Reproductive Timing in Marine Fishes: Variability, Temporal Scales, and Methods. Mar Coast Fish Dyn Manag Ecosyst Sci 3:71-91

Macbeth WG, Millar RB, Johnson DD, Gray CA, Keech RS, Collins D (2012) Assessment of the relative performance of a square-mesh codend design across multiple vessels in a demersal trawl fishery. Fish Res 134-136:29-41

- Macpherson E, Duarte CM (1991) Bathymetric trends in demersal fish size: Is there a general relationship? Mar Ecol Prog Ser 71:103-112

McBride RS, Somarakis S, Fitzhugh GR, Albert A and others (2013) Energy acquisition and allocation to egg production in relation to fish reproductive strategies. Fish Fish, doi:10.1111/faf.12043

McKay RJ (1992) FAO Species Catalogue, Vol 14. Sillaginid fishes of the world (family Sillaginidae). An annotated and illustrated catalogue of the Sillago, smelt or IndoPacific whiting species known to date. FAO, Rome

> Mercier A, Hamel JF (2010) Synchronized breeding events in sympatric marine invertebrates: role of behavior and fine temporal windows in maintaining reproductive isolation. Behav Ecol Sociobiol 64:1749-1765

> Methratta ET, Link JS (2007) Ontogenetic variation in habitat associations for four flatfish species in the Gulf of Maine-Georges Bank region. J Fish Biol 70:1669-1688

Middleton RW, Musick JA (1986) The abundance and distribution of the family Macrouridae (Pisces, Gadiformes) in 
the Norfolk canyon area. Fish Bull 84:35-62

Morgan MJ, Bowering WR (1997) Temporal and geographic variation in maturity at length and age of Greenland halibut (Reinhardtius hippoglossoides) from the Canadian north-west Atlantic with implications for fisheries management. ICES J Mar Sci 54:875-885

Morton RM (1985) The reproductive biology of summer whiting, Sillago ciliata C. \& V., in northern Moreton Bay, Queensland. Aust Zool 21:491-502

Muthiga NA (2003) Coexistence and reproductive isolation of the sympatric echinoids Diadema savignyi Michelin and Diadema setosum (Leske) on Kenyan coral reefs. Mar Biol 143:669-677

Nakane Y, Suda Y, Sano M (2013) Responses of fish assemblage structures to sandy beach types in Kyushu Island, southern Japan. Mar Biol 160:1563-1581

Nelder JA, Wedderburn WM (1972) Generalized linear models. J R Stat Soc A 135:370-384

Park YJ, Takemura A, Lee YD (2006) Annual and lunar-synchronized ovarian activity in two rabbitfish species in the Chuuk lagoon, Micronesia. Fish Sci 72:166-172

Parker GA (1992) The evolution of sexual dimorphism in fish. J Fish Biol 41:1-20

Quinn GP, Keough KJ (2002) Experimental Design and Data Analysis for Biologists. Cambridge University Press, Cambridge

Radhakrishnan N (1957) A contribution to the biology of the Indian sand whiting, Sillago sihama (Forskal). Indian J Fish 4:254-283

Rahman MH, Tachihara K (2005a) Reproductive biology of Sillago aeolus in Okinawa Island, Japan. Fish Sci 71: 122-132

Rahman MH, Tachihara K (2005b) Age and growth of Sillago aeolus in Okinawa Island, Japan. J Oceanogr 61: 569-573

Reddy CR, Neelakantan N (1992) Age and growth of Indian whiting, Sillago sihama (Forskal) from Karwar waters. Mahasagar 25:61-64

Roberts CM, Hawkins JP, Gell FR (2005) The role of marine reserves in achieving sustainable fisheries. Philos Trans R Soc B 360:123-132

Rochet MJ (1998) Short-term effects of fishing on life history traits of fishes. ICES J Mar Sci 55:371-391

Roff DA (1991) The evolution of life-history variation in fishes, with particular reference to flatfish. Neth J Sea Res 27:197-207

Roff DA (1992) The evolution of life histories: theory and analysis. Chapman \& Hall, New York, NY

Ross ST (1977) Patterns of resource partitioning in searobins (Pisces: Triglidae). Copeia 1977:561-571

Ross ST (1986) Resource partitioning in fish assemblages: a review. Copeia 1986:352-388

Roughan M, Middleton JH (2004) On the East Australian Current: variability, encroachment, and upwelling. J Geophys Res Oceans 109:C07003, doi:10.1029/2003JC001833

Roughan M, Macdonald HS, Baird ME, Glasby TM (2011) Modelling coastal connectivity in a Western Boundary Current: Seasonal and inter-annual variability. Deep-Sea Res II 58:628-644

Rowling K, Hegarty A, Ives MC (2010) Status of fisheries resources in NSW 2008/09. Industry and Investment NSW, Cronulla

Ruttenberg BI, Haupt AJ, Chiriboga AI, Warner RR (2005) Patterns, causes and consequences of regional variation

Editorial responsibility: Thomas Turner, Albuquerque, New Mexico, USA in the ecology and life history of a reef fish. Oecologia 145:394-403

Ryer CH, Laurel BJ, Stoner AW (2010) Testing the shallow water refuge hypothesis in flatfish nurseries. Mar Ecol Prog Ser 415:275-282

- Sala-Bozano M, Mariani S (2011) Life history variation in a marine teleost across a heterogeneous seascape. Estuar Coast Shelf Sci 92:555-563

> Sancho G, Solow AR, Lobel PS (2000) Environmental influences on the diel timing of spawning in coral reef fishes. Mar Ecol Prog Ser 206:193-212

Sarre GA, Potter IC (1999) Comparison between the reproductive biology of black bream Acanthopagrus butcheri (Teleosti: Sparidae) in four estuaries with widely differing characteristics. Int J Salt Lake Res 8:179-210

> Schoener TW (1974) Resource partitioning in ecological communities. Science 185:27-39

- Scott SG, Pankhurst NW (1992) Interannual variations in the reproductive cycle of the New Zealand snapper Pagrus auratus (Bloch \& Schneider) (Sparidae). J Fish Biol 41: 685-696

Shamsan EF, Ansari ZA (2010) Studies on the reproductive biology of the Indian sand whiting Sillago sihama (Forsskal). Indian J Mar Sci 39:280-284

> Sharpe DMT, Hendry AP (2009) Life history change in commercially exploited fish stocks: an analysis of trends across studies. Evol Applic 2:260-275

Stefanescu C, Rucabado J, Lloris D (1992) Depth-size trends in western Meditterranean demersal deep-sea fishes. Mar Ecol Prog Ser 81:205-213

Stocks J, Stewart J, Gray CA, West RJ (2011) Using otolith increment widths to infer spatial, temporal and gender variation in the growth of sand whiting Sillago ciliata. Fish Manag Ecol 18:121-131

Suthers IM, Young JW, Baird ME, Roughan M and others (2011) The strengthening East Australian Current, its eddies and biological effects-an introduction and overview. Deep-Sea Res II 58:538-546

Tomaiuolo M, Hansen TF, Levitan DR (2007) A theoretical investigation of sympatric evolution of temporal reproductive isolation as illustrated by marine broadcast spawners. Evolution 61:2584-2595

> Walsh CT, Gray CA, West RJ, Williams LFG (2011) Reproductive biology and spawning strategy of the catadromous percichthyid, Macquaria colonorum (Gunther, 1863). Environ Biol Fish 91:471-486

Wellenreuther M, Clements KD (2007) Reproductive isolation in temperate reef fishes. Mar Biol 152:619-630

Weng HT (1986) Spatial and temporal distribution of whiting (Sillaginidae) in Moreton Bay, Queensland. J Fish Biol 29:755-764

> Werner EE, Hall DJ, Laughlin DR, Wagner DJ, Wilsmann LA, Funk FC (1977) Habitat partitioning in a freshwater fish community. J Fish Res Board Can 34:360-370

West G (1990) Methods of assessing ovarian development in fishes: a review. Aust J Mar Freshw Res 41:199-222

Wright PJ, Trippel EA (2009) Fishery-induced demographic changes in the timing of spawning: consequences for reproductive success. Fish Fish 10:283-304

Zeller B, Rowling K, Jebreen E, O'Neill M, Winning M (2012) Stout whiting Sillago robusta. In: Flood M, Stobutzki I, Andrews J, Begg G and others (eds) Status of key Australian fish stocks reports 2012. Fisheries Research and Development Corporation, Canberra, p 396-400

Submitted: January 15, 2014; Accepted: May 26, 2014

Proofs received from author(s): July 3, 2014 